\title{
LYMPHOID GOITRES
}

$B y$ T. LevitT, M.A., F.R.C.S.Eng., F.R.C.S.Ed., F.R.C.S.I.

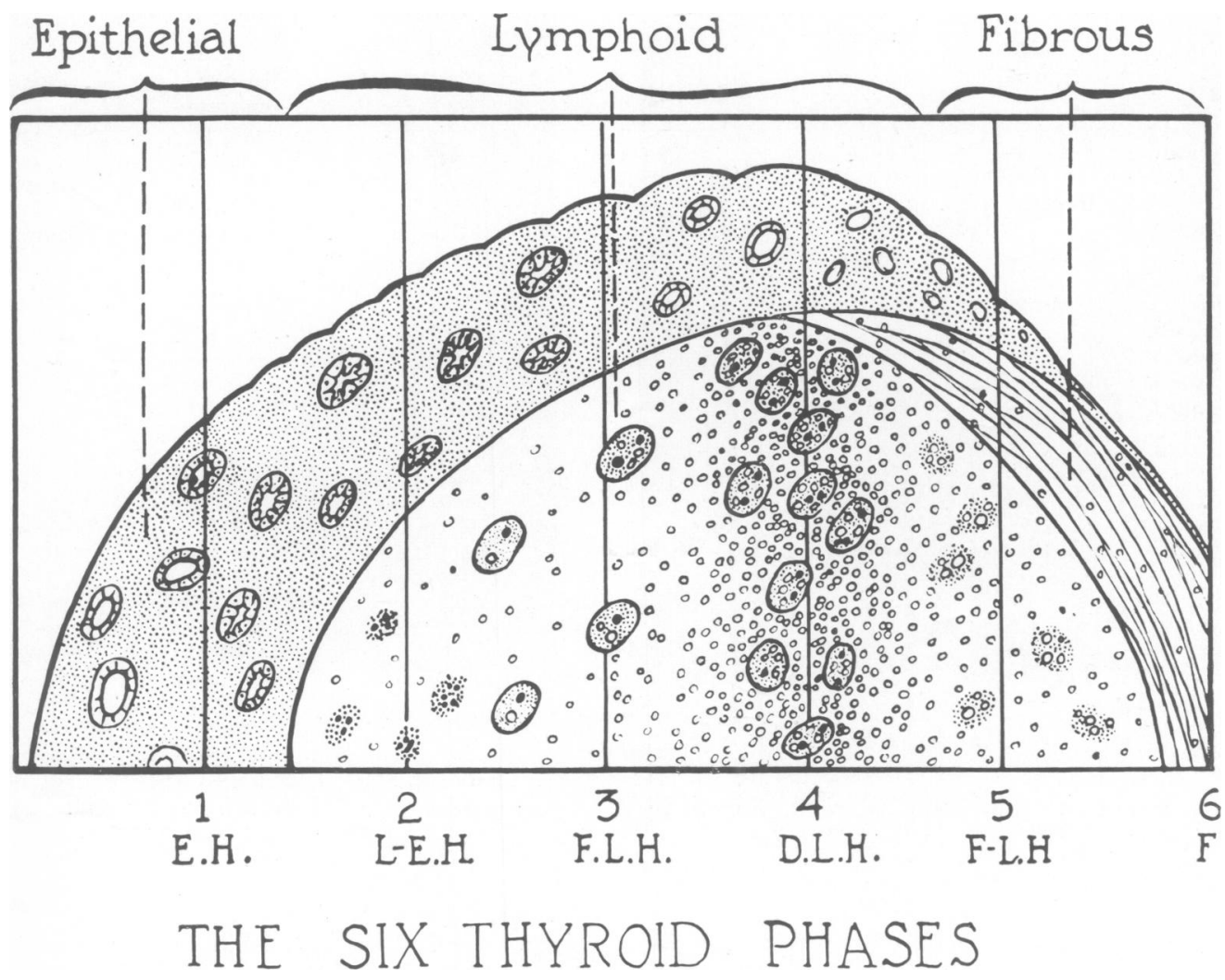

Fig. I

The past decade has witnessed a practical reorientation to the problem of so-called lymphadenoid goitre or struma lymphomatosa of Hashimoto. No longer is controversy so deeply centred as to whether this condition follows the epithelial hyperplasia of Graves or precedes the fibrosis of Riedel. Stress must now be laid on its practical aspects, the clinical recognition, treatment and, if possible, the final cure.

It is now becoming increasingly recognized that this thyroidal state is part of a general systemic dysfunction affecting not only the other endocrine glands, the pituitary, hypothalamus and cerebral cortex, but also the vital internal organs, such as the liver, spleen and kidneys.

The results of my work, published in 1951,1952 and 1953, will be referred to here in the briefest outline. I came to the conclusion that, following $\frac{\bar{\sigma}}{3}$. unremitting and continued stress, the thyroid gland underwent successive pathological changes which were mirrored by the clinical condition of $\mathrm{O}$ the patient. The epithelial tissue increases by steady hyperplasia. At the height of epithelialo hyperplasia lymphoid tissue appears and increases as perivascular lymphorrhages and as focal lym- $\sim$ phoid follicles; the epithelial tissue becomes hypo- N plastic. Following the greatest and diffuse hyper- N plasia of lymphoid tissue the latter in turn becomes $\sigma$ hypoplastic. Fibrous tissue then appears on the scene, at first focally, increasing pari passu with $\stackrel{\circ}{=}$ diminishing lymphoid tissue, to end in the terminal diffuse fibrosis.

In 195 I I named the progressive phases of the $\frac{T}{0}$ degenerating thyroid gland (Fig. I): 
I. Epithelial hyperplasia.

2. Lympho-epithelial hyperplasia (Graves's constitution).

3. Focal lymphoid hyperplasia (lymphoid thyrotoxicosis).
4. Diffuse lymphoid hyperplasia (lymphadenoid goitre).

5. Fibrolymphoid hyperplasia (Hashimoto-like $\stackrel{D}{\perp}$ disease).

6. Fibrosis (Riedel's fibrosis in sharp contrast to Riedel's inflammatory chronic thyroiditis).

Table I.-The Microscopical Appearance of the Thyroid in the Lymphoid Phases

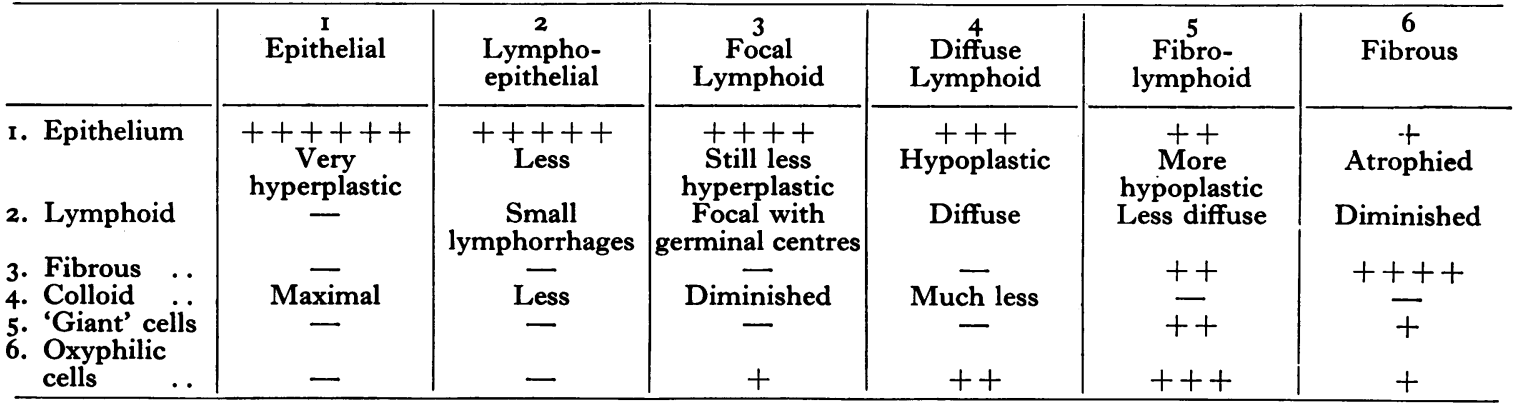

Table 2.-The Macroscopical Appearance of the Thyroid in the Lymphoid Phases

\begin{tabular}{|c|c|c|c|c|c|c|}
\hline & Epithelial & $\begin{array}{l}2 \\
\text { Lympho- } \\
\text { epithelial }\end{array}$ & $\begin{array}{c}\text { Focal } \\
\text { Lymphoid }\end{array}$ & $\begin{array}{c}4 \\
\text { Diffuse } \\
\text { Lymphoid }\end{array}$ & Fibrolymphoid & $\begin{array}{c}6 \\
\text { Fibrous }\end{array}$ \\
\hline $\begin{array}{l}\text { 1. Size } \\
\text { 2. Surface } \\
\text { Capsule }\end{array}$ & $\underset{\text { Translucent }}{\stackrel{+}{\text { Smooth }}}$ & $\begin{array}{c}++ \\
\text { Pebbly } \\
\text { Still shiny }\end{array}$ & $\begin{array}{c}+++ \\
\text { Bosellated } \\
\text { More opaque }\end{array}$ & $\begin{array}{c}++++ \\
\text { Lobular } \\
\text { Densely opaque }\end{array}$ & $\begin{array}{c}+++ \\
\text { Nodular } \\
\text { Fine extra- } \\
\text { capsular adhe- }\end{array}$ & $\begin{array}{c}++ \\
\text { Irregular } \\
\text { Coarse firm } \\
\text { adhesions }\end{array}$ \\
\hline 3. Consistency & Soft & Less soft & Firmer & $\begin{array}{c}\text { Rubbery } \\
\text { homogeneous }\end{array}$ & $\begin{array}{l}\text { Hard lobulated } \\
\text { by trabeculae }\end{array}$ & $\begin{array}{l}\text { Very hard; cuts } \\
\text { with difficulty; }\end{array}$ \\
\hline $\begin{array}{l}\text { 4. Colour } \ldots \\
\text { 5. Vascularity } \\
\text { 6. Pressure .. }\end{array}$ & $\begin{array}{c}\text { Beef-red } \\
+++++\end{array}$ & $\begin{array}{c}\text { Lighter red } \\
++++ \\
-\end{array}$ & $\begin{array}{l}\text { Pink } \\
+++ \\
-\end{array}$ & $\begin{array}{c}\text { Pinkish yellow } \\
++ \\
+\end{array}$ & $\begin{array}{c}\text { Yellowish white } \\
+ \\
++\end{array}$ & $\begin{array}{l}\text { White } \\
+\overline{+}+\end{array}$ \\
\hline
\end{tabular}

Table 3.-The Clinical Appearance of the Patient in the Lymphoid Phases

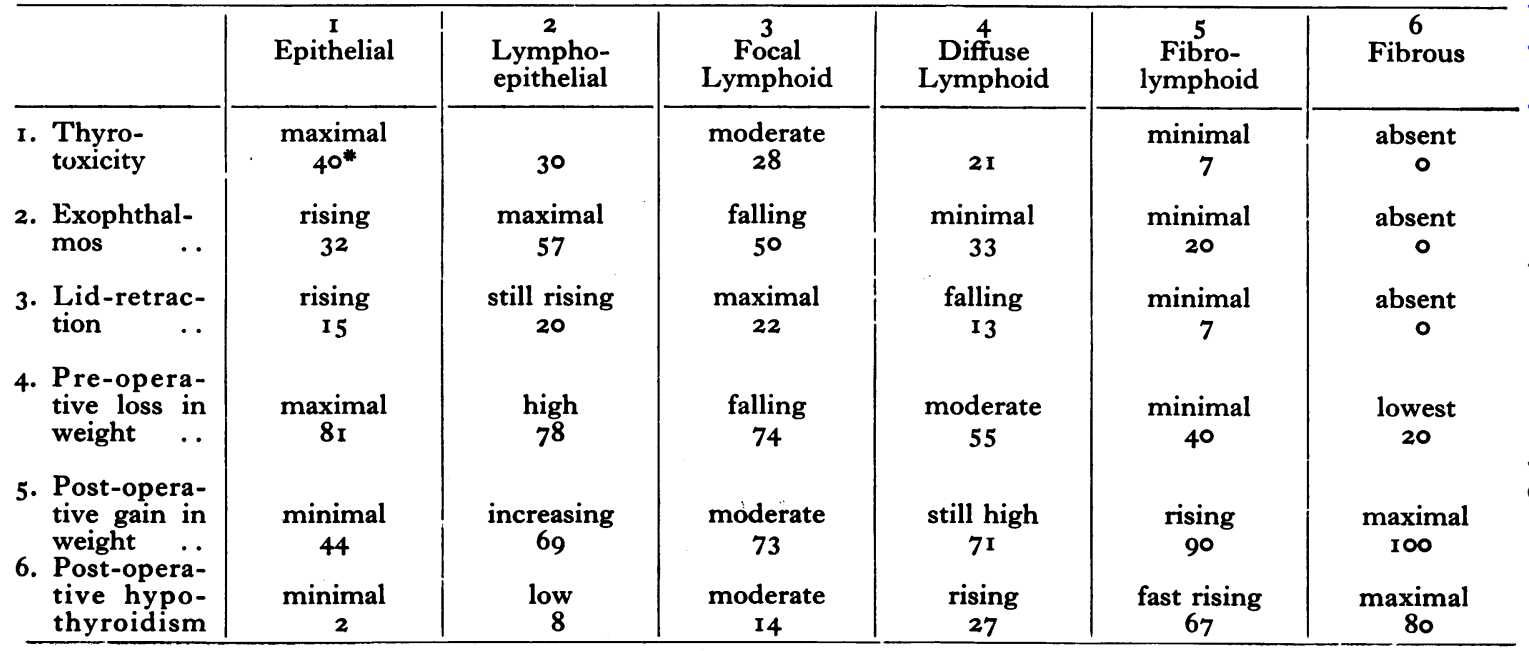


I further suggested that this sequence might progress to any phase and persist as such or may occasionally revert to a previous phase. The appearance of fibrous tissue would, however, ensure irreversibility of the affected part of the gland.

The epithelial element appears to be chiefly concerned with the growth and metabolism of the thyroid gland. The lymphoid deposition is in part reflected by the antibody-antigen reaction and the production of immunity against disease, as stressed in 'The Thyroid' (r953). The fibrous element appears to be part of the healing process, replacing the degenerated and atrophied epithelial and lymphoid tissues, but taking little or no part in the physiological and biochemical aspects of this phased process. Its complications are chiefly clinical.

As the phases advance the ages of the patients increase in concord with the gradual obliteration of the lumina of the blood vessels.

The microscopical features of these six phases are carefully defined in Table I and the macroscopical appearances of the gland are detailed in Table 2. The clinical criteria of the phases are shown in Table 3 and are expressed as a percentage of the I,4IO epithelio-lymphoid goitres which I have studied (Fig. 2). The truly epithelial goitres in this special series total 706, and the lymphoid goitres constitute 704 patients.

The pre-operative clinical, the operative macroscopical and post-operative clinical and microscopical criteria are postulated for each of these phases of the lymphoid goitre. Thus the clinician, the surgeon, the pathologist and, ultimately, the biochemist dealing with these lymphoid goitre patients for the first time become able to pinpoint the exact state of progression of this generalized systemic condition. Treatment becomes equally definitive for each phase.

It is this wide 'spectrum' of 704 lymphoid goitre patients who have been variously described by the terms Graves's constitution, lymphoid thyrotoxicosis, lymphadenoid goitre, Hashimoto's diseasc and Riedel's disease. More frequently, however, they have been included under the general designation ' Hashimoto's disease.'

Riedel, in all, reported three patients (Fig. 3), the first of whom appeared to suffer from fibrosis of the thyroid (my phase 6), a non-inflammatory condition, the termination of this phased chainprocess. In sharp contradistinction, his last two patients manifested chronic thyroiditis, a truly inflammatory condition which has no bearing on this spectrum of the six phases and will not be discussed here.

Hashimoto described four patients in whom he

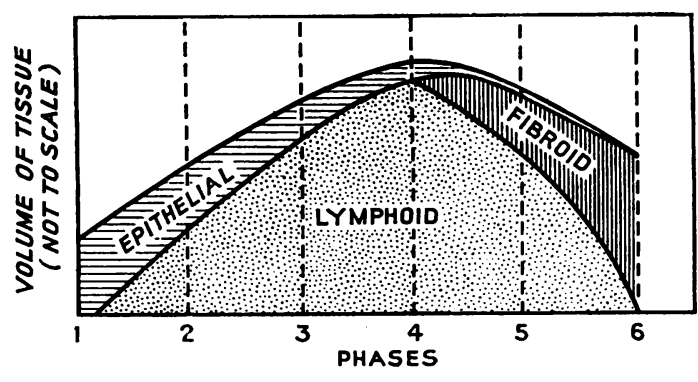

-Schematic representation of histology of six phases : I, epithelial hyperplasia ; 2, Iympho-epithelial hyperplasia; 3, focal Iymphoid hyperplasia ; 4, diffuse Iymphoid hyperplasia - 5. fibrolymphoid hyperplasia ; 6, fibrosis.
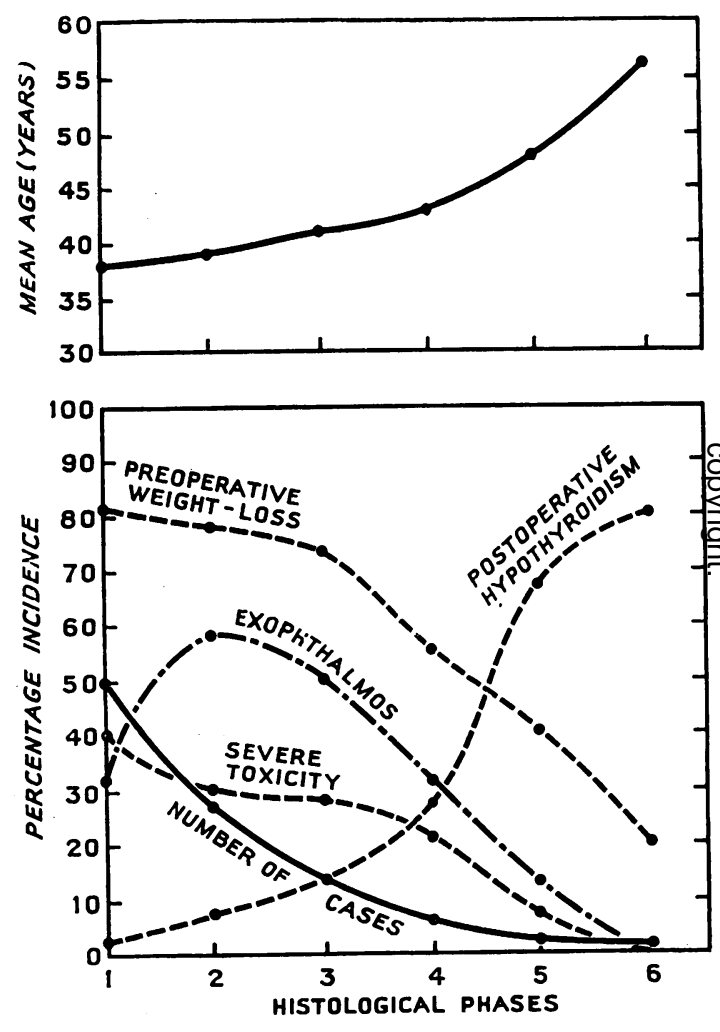

F:G. 2.

suspected and suggested a gradational progressive change. The first patient presented diffuse lymphoid hyperplasia (phase 4); the intermediate, second and third, that of fibrolymphoid hyperplasia (phase 5); the final patient suffered from fibrosis (phase 6) which very remarkably resembled the first of Riedel's three patients; but, as I emphasized in 1952, it differed from Riedel's inflammatory condition of chronic thyroiditis seen in his last two patients. 
SIX PROGRESSIVE THYROID PHASES

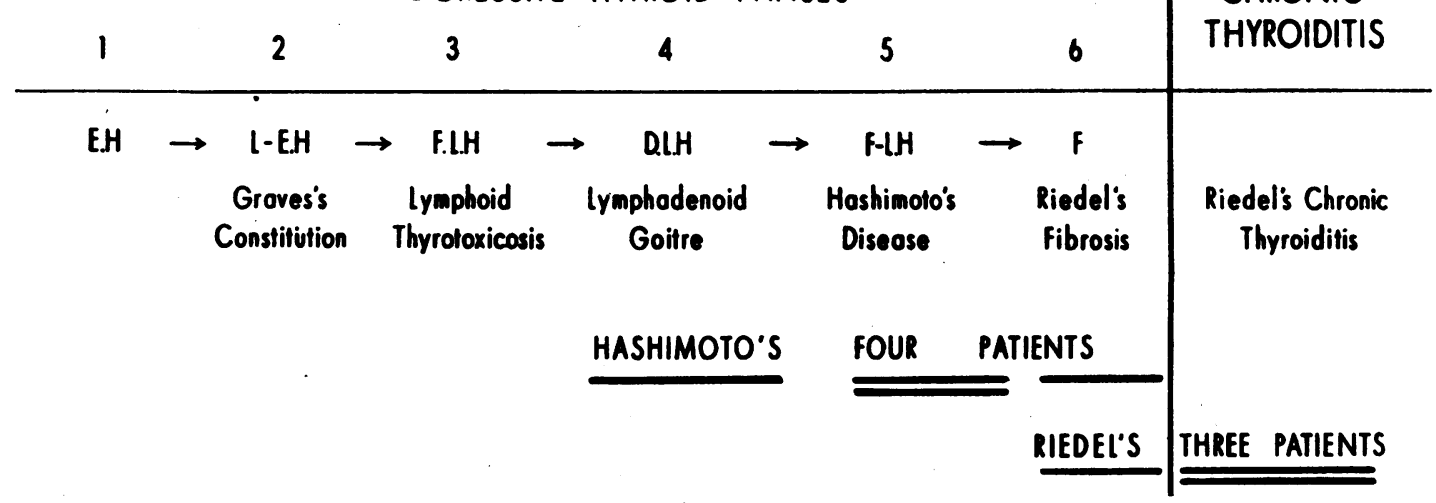

Fig. 3

The spectrum of so-called struma lymphomatosa of Hashimoto was so very wide that advance in the true scientific understanding of this process had become seriously hampered. Many different and apparently conflicting features had been attributed to the condition during the past half-century from I900 to I950. I found that the separation of this chain-process into six phases as described, and defining the attributes of each, very greatly simplified its understanding. Physiological, biochemical, radioiodine, clinical, prognostic and therapeutic features and correlations have become simplified and the stage of the patient's progression can be easily ' pinpointed.'

\section{Biochemical Tests}

The extensive range of reported biochemical findings reflects the wide spectrum of Hashimoto's struma lymphomatosa generally assessed by different workers, not only in separate centres, but also in the same institution.

Biochemical evidence of thyroidal failure may be associated with (a) an apparently euthyroid individual without symptoms or signs of thyroidal failure or (b) a hypothyroid patient with definite symptoms or signs of diminished thyroidal function. The former has been designated by Skillern and his colleagues at the Cleveland Clinic (1956) as compensated thyroidal failure and the latter group as uncompensated thyroidal failure. Any degree of thyroidal maladjustment intermediate between these may occur. The complexity of this problem becomes intensified if the whole spectrum is lumped under the all-comprehensive term ' struma lymphomatosa or Hashimoto's disease' instead of unravelling the whole into its parts. This analysis I attempted to do in $195^{1}$ by defining and correlating the progressive phases of the lymphoid goitre.
The more advanced phases of the lymphoid goitre, especially diffuse lymphoid hyperplasia and fibrolymphoid hyperplasia, show the following features:

The basal metabolic rate (B.M.R.) is usually low and forms a valuable index.

The serum cholesterol is elevated above $260 \mathrm{mg}$. per $100 \mathrm{ml}$. in the hypothyroid range and being occasionally above the myxoedematous range of $400 \mathrm{mg}$. per cent. It is a more valuable index in the later myxoedematous lymphoid phases.

The erythrocyte sedimentation rate (E.S.R.) iso raised.

The plasma proteins. Electrophoretic studies show very characteristic changes which not only serve to diagnose the condition, but also appear to differentiate it from malignant tumours of the thyroid. The superposition of malignant change on lymphoid goitres, as reported by an increasing number of observers, notably Lindsay (1955), makes this problem more difficult, however, to assess.

The albumens are usually low or fall to a lownormal figure.

The beta globulins may be high or reach the higher levels of normality.

The gamma globulins are very characteristically raised.

In a separate study of 40 cancers of the thyroid gland (1957) I have not found the gamma globulin greatly raised, although such an isolated occurrence has been reported by Robbins, Rall and Rawson (1.956) in a functional thyroid carcinoma.

Liver function tests. These are useful indices for diagnosis, prognosis and treatment of this systemic disease. The non-specific nature of these measurements, however, emphasize the need for viewing the biochemical picture as part of a whole and correlating it with the overall survey. 
The serum colloidal gold test, as observed by Cooke and Wilder (1954), forms a most valuable index in the evaluation of the earlier lymphoid phases where thyroidal failure is less severe. Its raised value may be due to the precipitation of the colloidal gold by the greatly increased content of the gamma globulin in the plasma protein.

The turbidity levels of thymol, zinc sulphate and ammonium sulphate are all raised with the greater deposition of lymphoid tissue.

The thymol flocculation test becomes positive in the later lymphoid phases and is a more useful index than the cephalin flocculation test.

\section{Radioiodine Tests}

The I ${ }^{131}$ tests for so-called Hashimoto's struma lymphomatosa, as recorded in the literature, show a wide range. They measure the change in the epithelial element and give no direct indication of the status of the lymphoid or fibrous tissues.

The thyroid uptake shows an extraordinarily wide variation. The 24-hour uptake has been reported as varying from below ro per cent. to above 95 per cent. This confirms the suspicion that the histological diagnosis, not only in different centres, but also in the same institution, covers a wide spectrum of lymphoid goitre, ranging probably from lympho-epithelial hyperplasia (phase 2) to fibrosis (phase 6).

This scatter of recorded results for 'Hashimoto's disease' is seen in the range of reported biological half-life, varying from 2 to 1o days in the same institution.

The thyrotropin stimulation test shows no increased uptake, indicating that the endogenous thyrotropin is already producing maximal stimulation of the epithelial cells of the thyroid.

The potassium perchlorate test has been described by Morgans and Trotter (1957). The administration of potassium perchlorate after the exhibition of $I^{131}$ was often followed by considerable loss of the radioiodine previously taken up by the socalled lymphadenoid goitre of Hashimoto. The extent of this resultant discharge of absorbed radioiodine from the thyroid is an index of the organic binding of iodine by the thyroid gland.

The total protein-bound iodine (P.B.I.) is low or attains the lower level of normality.

The serum butanol extractable iodine (B.E.I.) gives a similar result, indicating a low thyroid hormone level.

The topographical survey, as seen by the automatic scanner, shows an even, diffuse distribution of uptake delineating the size and shape of the affected thyroid gland unlike malignant disease or cystic change.
Autoradiography confirms this even distributi解 in lymphoid goitres.

\section{Immunological Tests}

In 1953 I recorded in 'The Thyroid' (p. I 49, 357) that hypoalbuminaemia, associated with absolute increase of beta and gamma globulins, accompanied the degeneration of the thyro몀 during the later lymphoid phases when the tef dency to myxoedema was greater. I then suggested that these lymphoid stores in the thyroid were concerned with antibody formation and that the extensive removal of an enlarged thyroid in the phase of diffuse lymphoid hyperplasia or its radical destruction by radiotherapy was unwise and diminished its ability to sustain an immunologica् action.

In order to detect and at the same time evaluate the strength of antigen-antibody reactions lymphoid goitres, the following tests are proving of value:

Precipitin test. This usually gives a reliabl reading and is readily performed. The precipitate is produced in vitro by the interaction of antigen derived from exogenous thyroglobulin with that of the antibody already present in the patient serum.

The complement fixation test, on the other hande is much more sensitive in man and therefore oret quires greater care in assessment. Cross reactrons with heterologous species may occur at an e⿳⺈⿴囗十 stage.

Tanned cell haemagglutination test. This hag proved very valuable in the hands of the Witebskg team; it also gives considerable cross reaction The erythrocytes (modified by dilute tannic acid are coated with the appropriate dilution of antigeniç thyroid extracts. These tanned red cells becomf agglutinated on the addition of serum from the lymphoid goitre patient which contains the antibody. Great sensitivity is obtained even $i \bar{g}$. high dilution.

The skin reactivity test, also used by Witebsk gives a positive reaction measured by the diametex of the erythema and intensity of the dermas induration.

In 1955 Witebsky and colleagues found that the degree of lymphoid change in rabbits immunizef with extracts of their own thyroids appeared to bo proportional to their antibody titre. Precipitins obtained in the sera of these animals were found tæ be organ-specific against the rabbit thyroid.

The precipitin test in man, as used by Roit and his co-workers (1956) at the Middlese Hospital, London, marked an important advancee⿱ They found that patients with 'Hashimoto's disease' gave a positive precipitin test, unlike normal subjects and patients with other thyroic 
Table 4.-Treatment of Patient in the Lymphoid Phases

\begin{tabular}{|c|c|c|c|c|c|c|}
\hline & Epithelial & $\begin{array}{l}2 \\
\text { Lympho- } \\
\text { epithelial }\end{array}$ & $\begin{array}{c}\text { Focal } \\
\text { Lymphoid }\end{array}$ & $\begin{array}{c}4 \\
\text { Diffuse } \\
\text { Lymphoid }\end{array}$ & Fibrolymphoid & $\begin{array}{c}6 \\
\text { Fibrous }\end{array}$ \\
\hline $\begin{array}{l}\text { 1. Thiouracil } \\
\text { 2. Radioiodine } \\
\text { 3. Thyroidec- } \\
\text { tomy } \\
\text { 4. Residue } \\
\text { retained } \\
\text { 5. Ligation of } \\
\text { arterial } \\
\text { pedicles } \\
\text { 6. Thyroid } \\
\text { therapy } \\
\text { required }\end{array}$ & $\begin{array}{c}++ \\
++ \\
++++++ \\
\text { Most valuable, } \\
\text { prevents recur- } \\
\text { rence } \\
+ \\
\text { Smallest } \\
++ \\
+\end{array}$ & $\begin{array}{c}++++ \\
++ \\
++ \\
+\end{array}$ & ++++ & +++ & $\begin{array}{c}++ \\
\text { Excludes } \\
\text { relieves } \\
+++++\end{array}$ & $\begin{array}{c}\quad+ \\
\begin{array}{c}\text { Less valuable } \\
\text { malignancy } \\
\text { pressure } \\
++++++ \\
\text { Largest }\end{array} \\
- \\
+++ \\
+\end{array}$ \\
\hline
\end{tabular}

diseases. Furthermore, the antibodies were found to be organ-specific to the human thyroid gland. It was suggested that patients with lymphadenoid goitre were immunized against human thyroglobulin and that the destruction of their thyroid gland resulted from the progressive interaction of the thyroglobulin in the gland with the autoantibody present in the patient's serum.

Fluorescein stain test, as evolved by White (1957) of the London Hospital, marks a further recent advance. Preparations of sections of human thyroid are treated with fluorescein conjugates of the globulin fraction of the same patient's serum which contains the antibodies. Localization of the conjugate occurs in the intraacinar colloid. The same conjugate will localize to other human and monkey thyroid sections. These facts support the hypothesis that the antigen concerned is present in other thyroids than those pathologically involved. Normal thyroids show antigen in the acini and within the colloid. The thyroids of lymphoid goitres show the antigen free among the lymphoid cells surrounding the acini.

The possible role of periacinar colloid extrusion in the production of lymphoid goitres was reported by Hellwig (1951) and by Levitt (1952 and I953).

The lymphoid hyperplasias of the other target endocrine glands such as the adrenal cortices, gonads and secondary sexual organs may most probably be part of a similar systemic immunological process.

\section{Treatment}

Adequate treatment by means of desiccated thyroid produces a diminution in size of the thyroid and a decrease in the hypothyroid stigmata. The radioiodine and biochemical reactive levels may thus be made to revert to normal or near-normal levels.

The danger of malignant change in a lymphoid goitre cannot be stressed too strongly. If any suspicion of such neoplastic degeneration is awakened, adequate incisional biopsy is necessary. Needle biopsies are easy to do, but often provide misleading information.

The chief features of treatment are summarized in Table 4. As the phases advance from $I$ to 6 the extent of the thyroidectomy must of necessity become smaller because the possibility of postoperative hypothyroidism increases steadily. The size of the residue left behind must therefore become larger in order to minimize this myxoedematous change. The necessity for ligation of the arterial pedicles becomes minimal after the phase of focal lymphoid hyperplasia. The need for post-operative thyroid medication increases steadily from phase 3 to phase 6 .

Focal lymphoid hyperplasia is adequately treated by means of desiccated thyroid if there is no danger of malignant change.

Diffuse lymphoid hyperplasia is still reversible, reacting well to thyroid therapy.

Fibrolymphoid hyperplasia, with its increasing fibrosis, may produce severe pressure phenomena. The enlarged lymphoid element reacts well to thyroid substitution therapy. Its steadily augmenting fibrosis indicates the necessity for relief of pressure by isthmectomy or wedge excision. If severe constriction ensues, limited partial thyroidectomy is required, followed by adequate postoperative thyroid medication. This ensures a maintained and balanced euthyroid state. The operative intervention affords the added opportunity for excluding any malignant change.

The rare terminal fibrosis always requires surgical intervention and treatment by wedge excision, as the differentiation from malignant disease is very difficult and constrictive processes are always present. 


\section{The Future}

In the same manner as I have defined the different criteria for the phases of the degenerating thyroid, I am completing the overall biochemical picture for each of these six phases. This data, especially for the most recently evolved tests, is not yet statistically significant. Similar radioiodine trends correlating the microscopical with the macroscopical and clinical features have become. generally obvious.

It would, for instance, be important to assess definitively when and how the titre of the precipitin test changes in each of these phases, the different types and contours of the gold colloidal test, the changing intensity of the turbidity tests and to plot the accurate levels of the plasma proteins, especially the gamma globulin in each phase. Then, and then only, will we have an accurate and scientific yardstick to evaluate the validity of this concept of phased progression.

Finer assessment of subjective and clinical change in thyroidal dysfunction, with its periodic or rhythmic fluxes subclinical manifestations and the variations of measurement by differently trained observers, is notoriously difficult. Basically, we require an accurate pathological picture of the predominant phase of the whole thyroid gland. In addition, we have to accumulate an adequate number of objective biochemical and radioiodine and immunological criteria for assessing the validity of this concept.

A large, virtually unexplored, field lies wide open.

The apparent wide range of the recorded biochemical and radioiodine levels in so-called struma lymphomatosa or 'Hashimoto's disease' may fall into place when studied from these analyse phases.

I would reiterate the plea I made in $195^{2}$, tha the many eponymous designations associated witl the 'dark ages' of thyroid disease be replacel by more precisely defined terminology an nomenclature.

\section{Conclusion}

$A$ representative international conference woul constitute an admirable forum for finally bringing order into the contentious problem of lymphoid goitre

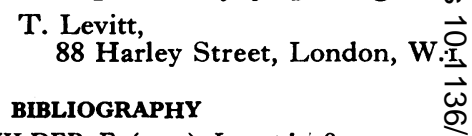

COOKE, R. T., and WILDER, E. (1954), Lancet i, ' 984 .

DONIACH, D., HUDSON, R. V., (1957), Brit. Med. f., 1, ${ }^{6} 672 \frac{\mathrm{C}}{3}$

HASHIMOTO, H. (1912), Arch. Klin. Chir., 97, 219

HELLWIG, C. A. (195I), Science, 113, 725.

LEVITT, T. (1951), Lancet, ii, 957.

LEVITT, T. (1952), Ann. Roy. Coll. Surgeons, 10, 369.

LEVITT, T. (r953), ' The Thyroid : a Physiological, Pathologicat! Clinical and Surgical Study ', Edinburgh, E. S. Livingstone,

LEVITT, T. (1957), in process of publication.

LINDSAY, S., DAILE $Y$, M. E. (1955), fnl. clin. Endocr. ang Metab., 14, 1332.

LUXTON, R. W., and COOKE, R. T. (1956), Lancet, ii, 105. MORGANS, M. E., and TROTTER, W. R. (1957), Lancet, i, $55 \overrightarrow{3}$. RIEDEL, B. M. K. L. (1896), Verh. deutsch. gesellsch. chr., 25, 75. RIEDEL, B. M. K. L. (1897), Verh. deutsch. gesellsch. chr., 26, i 27. RIEDEL, B. M. K. L. (1910), Munchen med. wschnschr., 57, 1946 ROBBINS, J., RALL, J. E., and RAWSON, R. W. (1956惫 ROITT, I. M., DONIACH, D., CAMPBELL, P. N., sand HÚDSON, R. V. (1956), Lancet, ii, 820.

ROSE, N. R., and WITEBSKY, E. (1956), f. Immunol., 76, 슨 SKILLERN, P. G., CRILE, G., MCCULLAGH, E. P., HAZARIM J. B., LEWIS, L. A., and BROWN, H. (1956), $\mathcal{f}$. clin. EndocO and Metab., 16, 35 .

WHITE, R. G., (1957), personal communication.

WITEBSKY, E., ROSE, N. R., SHULMAN, S., (1955), Immunol. 75, 269.

\section{H. K. LEWIS \& Co. Ltd.}

Medical Publishers and Booksellers

\section{GOWER STREET LONDON, W.C. 1} (Adjoining University College and Hospital)

Tolephone: EUston 202 (7 linee)

Telegroms: Publicavit, Wereent, Loaden Established 1844

\section{Medical Lending Library}

ANNUAL SUBSCRIPTION from $t / 17 s$. $6 d$.

Prospectus post free on application

Bi-monthly List of New Books and New Editions added to the Library sent post free on request

The Library Catalogue revised to December, 1949, containing a classified index of authors and subjects.

To subscribers 10/- net; To non-subscribers 17/6 net. Postage 1/9

Supplement 1950 to 1952 . To subscribers $1 / 6$ net; to nonsubscribers $3 /-$ net; postage $8 \mathrm{~d}$.

NEW BOOKS ADDED IMMEDIATELY UPON PUBLICATION 